\title{
NEST STRUCTURE AND COMMUNAL NESTING IN EUGLOSSA (GLOSSURA) ANNECTANS DRESSLER (HYMENOPTERA, APIDAE, EUGLOSSINI)
}

\author{
Carlos Alberto Garófalo ${ }^{1}$ \\ Evandro Camillo ${ }^{1}$ \\ Solange Cristina Augusto ${ }^{1}$ \\ Bartira Maria Vieira de Jesus ${ }^{1}$ \\ José Carlos Serrano ${ }^{1}$
}

\begin{abstract}
Three nests of Euglossa (Glossura) annectans Dressler, 1982 were obtained from trap nests at Serra do Japi, Jundiai, São Paulo State, Brazil. The bees nested in bamboo cane (one nest) and in wooden-boxes (two nests). Solitary (two cases) and pleometrotic (one case) foundations were observed. Two nests were re-used once by two females working in each of them. Re-using females that shared the nests were of the same generation and each built, provisioned and oviposited in her own cells, characterizing a communal association. The brood development period was related to climatic conditions. Natural enemies included Anthrax oedipus oedipus Fabricius, 1805 (Bombyliidae), Coelioxys sp. (Megachilidae) and Melittobia sp. (Eulophidae).

KEY WORDS. Apidae, Euglossini, Euglossa annectans, nesting biology, nest re-use
\end{abstract}

Very little is known about the nest structure and nesting habits of the Euglossini. Nests of only eight species of Eufriesea Cockerell, 1908, three species of Eulaema Lepeletier, 1841 and 21 species of Euglossa Latreille, 1802 have been described; these figures correspond to $18.1 \%$ of the species of three genera (GARÓFALO 1994). The little information available on such aspects is due to the fact that the nests of these bees are not easily found (MICHENER 1974; DRESSLER 1982; KIMSEY 1987). Utilizing the trap nest technique, GARÓFALO et al. (1993) obtained 16 nests of four species of Euglossa and 10 nests of Eufriesea auriceps (Friese, 1899). Although species that utilize subterranean cavities or ant nests or build aerial nests can not be expected to nest in these traps, the authors concluded that placing trap nests in several areas would be more effective than searching for the nests in the field.

This paper presents observations on nest structure and nesting biology of Euglossa (Glossura) annectans Dressler, 1982 from nests found in trap nests.

1) Departamento de Biologia, Faculdade de Filosofia, Ciências e Letras, Universidade de São Paulo. 14040-901 Ribeirão Preto, São Paulo, Brasil. 


\section{MATERIAL AND METHODS}

\section{Study sites}

Trap nests were placed at Base de Estudos de Ecologia e Educação Ambiental da Secretaria Municipal de Jundiai, São Paulo State, Brazil. The Base is located at Serra do Japi ( $\left.23^{\circ} 11^{\prime} \mathrm{S} ; 46^{\circ} 52^{\prime} \mathrm{W}\right)$, at $1050 \mathrm{~m}$ of altitude. Serra do Japi is covered mainly by semideciduous mesofitic forests (LEITÃO-FILHO 1992), and is characterized by altitudes ranging between $700 \mathrm{~m}$ and $1300 \mathrm{~m}$ and mean annual temperature between $15.7^{\circ} \mathrm{C}$ and $19.2^{\circ} \mathrm{C}$, according to altitude. The wet season extends from September to February with the wettest months being December and January $(>250 \mathrm{~mm})$; and the dry season extends from February to August $(<41 \mathrm{~mm})$ (PINTO 1992).

The nests of $E$. annectans established in the trap nests were removed to the laboratory located on the University Campus of Ribeirão Preto, São Paulo State, Brazil, where the observations on the re-use of nests were made. Ribeirão Preto $\left(21^{\circ} 11^{\prime} \mathrm{S} ; 47^{\circ} 13^{\prime} \mathrm{W}\right)$ has altitudes ranging from $580 \mathrm{~m}$ to $620 \mathrm{~m}$. The cool and dry season extending from May to August, with the mean monthly temperature being $<22^{\circ} \mathrm{C}$ and precipitation $<65.0 \mathrm{~mm}$; and the hot and wet season extending from September to April with the mean monthly temperature ranging from $22.8^{\circ}-26.3^{\circ} \mathrm{C}$ and precipitation from $53.0 \mathrm{~mm}-295.3 \mathrm{~mm}$.

\section{Methodology}

Two types of trap nests were utilized. Firstly, bamboo canes, with variable diameters and lengths, which were cut so that the nodal septum closed one end of the cane; these canes were placed horizontally in bundles of 4-6 units along shelves in a shelter built at the study site. Secondly, small wooden-boxes (inside dimensions $8.5 \times 8.5 \times 5.0 \mathrm{~cm}$ ), covered with a glass plate, with a $17 \mathrm{~mm}$ circular entrance hole on one side, which were placed along with the bamboo traps. The trap nests were inspected once a month.

Three nests of $E$. annectans were obtained from trap nests. Nests 1 and 3 were established in wooden-boxes and the nest 2 in a bamboo cane. Nest 1 was found and removed to the laboratory on April 10, 1996. Nests 2 and 3 were found on April 10 and May 5, 1996, respectively, and left at their original places. Both nests were collected only in the next inspection so that each could continue active during another month.

In the laboratory the bamboo cane containing nest 2 was opened to analyse its contents. After that, the cane was placed in a wooden-box (inside dimensions 20 $x 5 \times 5 \mathrm{~cm}$ ) covered with a glass plate, to prevent the escape of emerging adults, and left undisturbed, as were the nests 1 and 3 in wooden-boxes, until the adults emerged. After the emergence of a female the wooden-boxes were placed on the shelves of a shelter built near the laboratory. Observations of the activities of the bees occupying the nests were made daily through the glass. The bees were marked for individual recognition using dots of paint placed on the thorax. Foraging behaviour of individuals females was studied in nest 3 only. Observations were made during 12 days from September 27 to October 18, 1996.

The statistical test is from ZAR (1984). 


\section{RESULTS}

\section{Nest structure and emergence of adults}

The nests did not show any inner wall coating. Nests 1 and 3 had resinous particles deposited near the entrance, on the floor of the wooden-boxes, most of them near the cells; also in these nests all cracks and joints were sealed with resin. Nest 2 was established in a bamboo cane about $1.6 \mathrm{~cm}$ in internal diameter and 19.4 $\mathrm{cm}$ long; the bamboo cane length occupied by the nest was $12.4 \mathrm{~cm}$. This nest had in its anterior part a resinous wall in which there was a small circular hole just large enough for the female to pass; also in nests 1 and 3 the entrance hole was constricted with resin. In all nests the cells were made of dark-brown resin; in nest 1, however, various particles of white resin were placed around the cells and on their wall.

The cells from nest 1 were made on the floor and formed two clusters about $1.4 \mathrm{~cm}$ distant for each other. One cluster $(=\mathrm{A})$ contained 4 sealed cells and the other (=B) 4 sealed cells and 1 being provisioned. The cells showed a flattened spheroid shape and were about $13-16 \mathrm{~mm}$ long by $8-10 \mathrm{~mm}$ wide; they were arranged in a comb-like fashion (Fig. 1). The two adult females inhabiting the nest were inseminated and had developed ovaries. Two females (one from each cluster) and one parasite, Coelioxys sp. (Megachilidae), emerged from this nest between 23 June and 19 July 1996 . The five others sealed cells failed to produce adults. These cells were opened on July 27. Four cells contained dead female pupae and the other cell parasitized by a bombyliid fly larva was being attacked by Melittobia sp. (Eulophidae).

Nest 2 contained one adult female and seven rowed sealed cells; the cells were built in two isolated series, one with two cells and the other with five with the cells of each series built in close contact (Fig. 2). The cells showed an elliptical shape and were about $13-15 \mathrm{~mm}$ long and 7-9 $\mathrm{mm}$ wide. The first adult, a female, emerged on August 1 and disappeared from the nest four days later. The second adult, a male, emerged six days after the female. Of the five remaining cells, one contained a dead male pupa, two contained Coelioxys sp. dead pupae and two were infested by Melittobia sp.

Nest 3 contained one adult female and five sealed cells built on the floor of the wooden-box. The cell arrangement was combed and the cells showed an elliptical shape. The first adult emerging was a bombyliid fly (Anthrax oedipus oedipus Fabricius, 1805) on 4 September followed by two female bees emerged on 9 and 15 September. The two other cells contained dead larvae.

\section{Nest re-use}

Nests 1 and 3 were re-used by the two females that emerged from each of them. In both nests the activities of cell construction or re-use of the old ones and cell provisioning were performed by each female independently.

The re-use process of nest 1 occurred from late cool and dry season to early hot and wet season (August-September). The duration of this process (from beginning of foraging for larval food until the last oviposition) was 53 days. The females 1 and 2 started foraging activities when they were 39 and 29 days old and made their first oviposition when they were 46 and 32 days old, respectively. Each female 

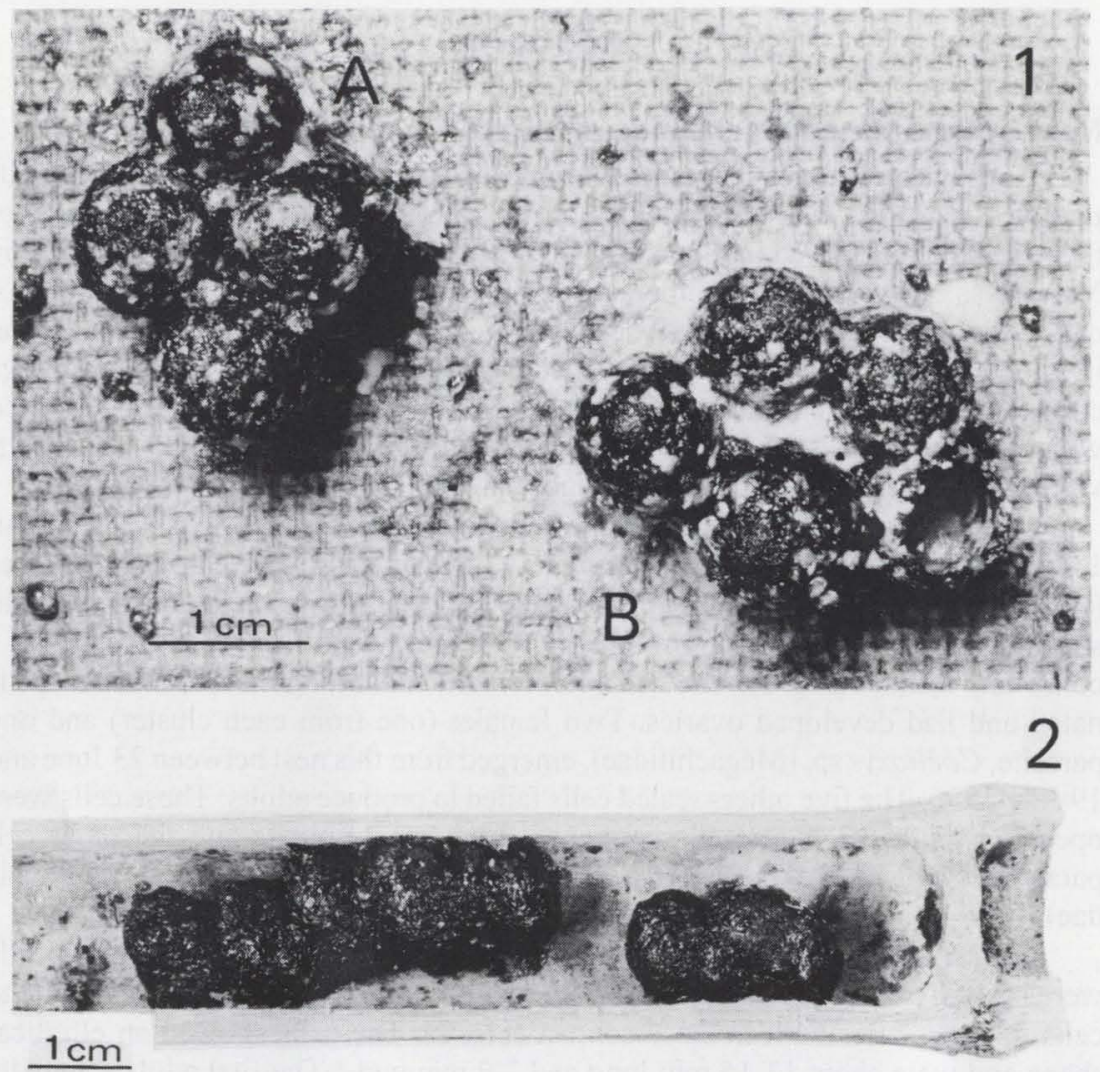

Figs 1-2. Euglossa annectans. (1) Cell clusters A and B found in nest 1 established in a wooden-box; (2) nest 2 established in a bamboo cane showing the rowed cell arrangement.

provisioned and oviposited nine cells, and the intervals between two consecutive ovipositions by the same female ranged from two to six days, for female 1 , and from two to seven days, for female 2 (Tab. I). Both females began their reproductive activities re-using the cells from the old cluster $\mathrm{A}$. Of the four cells of that cluster, three of them were utilized by female 1 and the other one by female 2 . After re-use of the old cells the females built 10 new cells around them giving the new cluster the appearance of a comb. Subsequently, female 1 re-used a cell from old cluster B and female 2 re-used two other cells from the same cluster. The last oviposition by female 2 was made in a cell built on the cells of cluster A. All ovipositions observed $(\mathrm{n}=12)$ were made in the afternoon. The female 1 disappeared from the nest 15 days after her last oviposition and before her offspring emerged; the time of residence in the nest for this female was 90 days. The disappearance of female 2 occurred 54 days after her last oviposition and it was in the nest when the emergences began to occur. This female disappeared from the nest when at the age of 124 days (Tab. I). 
Table I. Period of permanence in the nest and reproductive activities of each female during the re-use processes in two nests of Euglossa annectans.

\begin{tabular}{lllllll}
\hline \multirow{2}{*}{ Date of: } & \multicolumn{2}{c}{ Nest 1 } & & \multicolumn{2}{c}{ Nest 3 } \\
\cline { 2 - 3 } \cline { 5 - 6 } & Female 1 & Female 2 & & Female 1 & Female 2 \\
\cline { 2 - 3 } Emergence & June 23 & July 14 & & Sept. 9 & Sept. 14 \\
Start of larval food foraging & Aug. 1 & Aug. 12 & & Sept. 16 & Sept. 25 \\
1st oviposition & Aug. 8 & Aug. 15 & & Sept. 27 & Sept. 28 \\
2nd oviposition & Aug. 12 & Aug. 19 & & Sept. 30 & Oct. 2 \\
3rd oviposition & Aug. 14 & Aug. 22 & & Oct. 4 & Oct. 7 \\
4th oviposition & Aug. 16 & Aug. 24 & & Oct. 8 & Oct. 11 \\
5th oviposition & Aug. 19 & Aug. 29 & & Oct. 11 & Oct. 15 \\
6th oviposition & Aug. 22 & Sept. 5 & & Oct. 15 & Oct. 20 \\
7th oviposition & Aug. 26 & Sept. 11 & & Oct. 21 & \\
8th oviposition & Aug. 30 & Sept. 16 & & & \\
9th oviposition & Sept. 5 & Sept. 22 & & & \\
Disappearance from the nest & Sept. 20 & Nov. 15 & & Nov. 9 & Oct. 23 \\
\hline
\end{tabular}

A total of 13 bees and a bombyliid fly (Anthrax oedipus ssp.) emerged from 18 cells oviposited by females; the four remaining cells contained dead larvae. The first adult emerging was the bombyliid fly; this parasite emerged 72 days after the cell from which it was reared had been oviposited by female 2 . The egg-to-adult period for bees ranged from 75 to 87 days $(\bar{x}=80.6 \pm 3.8$ days; $n=13)$. Of the 13 bees produced, one female and three males were observed emerging; the nine remaining bees, females and/or males, emerged when the nest was not being observed. The female observed emerging was the only bee returning to the nest. Two days after this female emerged the female 2 disappeared from the nest. The new female stayed in the nest for 23 days only; then, the nest was not re-used again.

Nest 3 was re-used during the early and mid hot and wet season (September-October) and the duration of this process lasted 36 days. In this nest the females 1 and 2 started foraging for larval food when they were seven and eleven days old, respectively (Tab. I). The females began foraging between 5:00 and 6:00 $\mathrm{h}$ when the air temperature exceeded $17^{\circ} \mathrm{C}$, and continued until 12:00 or 13:00 $\mathrm{h}$ when the temperature rose above $27^{\circ} \mathrm{C}$. During that period the bees performed four to eight larval food collecting trips per day and after that they remained in the nest for three to four hours and then either made one or two trips, returning with resin or without any material on the legs. Larval food collecting trips ranged from 22 to 85 minutes $(\vec{x}=42.3 \pm 14.6$ minutes; $n=109)$ and time spent in the nest between larval food collecting trips was less than one minute. The age at which females made their first ovipositions was 18 and 14 days, and the interval between two consecutive ovipositions made by each of them ranged from three to six days and from three to five days, for females 1 and 2, respectively. Female 1 provisioned and oviposited seven cells and female 2, six cells. Both females disappeared from the nest before their offspring emerged and this occurred 19 days and three days after females 1 and 2 , respectively, had made their last ovipositions. The total time of permanence in the nest was 62 days for female 1 and 40 days for female 2 (Tab. I). As observed in nest 1 , before building new cells the females re-used three old cells; the first two ovipositions of female 1 and the first oviposition of female 2 were made in the 
re-used cells. The new cells were added to the sides of previous cells without particular directional order resulting in an irregularly clustered arrangement. Of the 10 ovipositions observed, seven were made in the morning and three in the afternoon. The total duration from oviposition to adult emergence took from 62 to 69 days $(\bar{x}=66.1 \pm 1.9$ days; $n=13)$ and it was significantly different from that observed for nest 1 (Mann-Whitney test, $Z=4.31 ; P<0.01$ ). Of the 13 individuals produced during the reactivation only three females and five males were observed emerging. This nest was not re-used again.

\section{DISCUSSION}

After reviewing all published descriptions of nests, ZUCCHI et al. (1969) stated that each nest of Euglossini is founded by a lone female and the presence of more than one female in nests of some species of Euglossa and Eulaema is the result of nest re-use by succeeding generations. This statement has been confirmed by more recent data for several species (GARÓFALO 1985, 1992; YoUNG 1985; EBERHARD 1988; RoubiK 1989; PEREIRA-MARTINS 1991; PEREIRA-MARTINS \& KERR 1991; GARÓFALO et al. 1993; SANTOS \& GARÓFALO 1994; RAMÍREZ-ARRIAGA et al. 1996). The results obtained in this study, however, showed that nests of E. annectans may be established by two ways: solitary nest foundation, as related to all so far studied species, and pleometrotic foundation, the first documentation of this occurrence for an euglossine species. Therefore, nest sharing in this species occurs not only during nest re-use but also during the foundation of a new nest, as described in this study.

The nesting by $E$. annectans in bamboo cane and wooden-boxes shows the behavioural plasticity of this species to use cavities of different sizes resulting, as showed in this study, in the occurrence of different cell arrangement patterns. Similar results were reported by GARÓFALO et al. (1993) for Euglossa truncata Rebêlo \& Moure, 1995, whose nests had been established in traps like to those utilized by $E$. annectans. Although the cell arrangement is a variable character among the genera of Euglossini, its occurrence within the same species is due to spatial limitation of cavity containing the nest (ZuCCHI et al. 1969).

Although the results obtained can not be considered as definitive, the maximum number of cells built by a female of $E$. annectans was smaller than that related for foundress females of Euglossa cordata (Linnaeus, 1758) (10 cells) (GARÓFALO 1985, 1992), E. truncata (12 cells) and Euglossa townsendi Cockerell, 1904 (11 cells) (GARÓFALO et al. 1993) and Euglossa atroveneta Dressler, 1978 (10 cells) (RAMÍREZ-ARRIAGA et al. 1996). The small number of sealed cells found in nest 1 and the presence of one cell being still provisioned indicate that both females did not have finished their reproductive activities when it was collected.

As showed in this study, and as observed by SANTOS \& GARÓFALO (1994) in Eulaema nigrita Lepeletier, 1841, the time of residence of re-using females in the nests was highly variable. The females from nest 1 stayed in the nest for longer time than those from nest 3 . This was mainly due to the differences in the duration of the pre-reproductive periods of females. Undoubtedly, the emergence of females from nest 1 under adverse climatic conditions (in the mid cool and dry season)

Revta bras. Zool. 15 (3): 589 - 596, 1998 
delayed the beginning of their reproductive activities. Besides, the post-reproductive period of female 2 from nest 1 was also very long. The total time of permanence in the nest of female 2 was only smaller than those related by GARÓFALO (1985), for one dominant female of E. cordata (191 days), and EBERHARD (1988), for one female of Euglossa hyacinthina Dressler, 1982 (at least, 171 days).

The difference in the duration of brood development observed between the nests was due to different climatic conditions when the re-use processes occurred. Similar results were related by GARÓFALO (1985), for E. cordata, GARÓFALO et al. (1993), for Euglossa pleosticta Dressler, 1982 and E. truncata, and SANTOS \& GARÓFALO (1994), for Eulaema nigrita.

Coelioxys, Anthrax and Melittobia were the organisms associated with the nests of $E$. annectans. The two first parasites had already been reared from nests of E. pleosticta, E. truncata, E. townsendi and Euglossa aff. melanotricha Moure, 1967, all of which had been established in traps (GARÓFALO et al. 1993). Observations on the attacks of Coelioxys on Euglossa nests were also reported by RAMírEZARRIAGA et al. (1996). According to these authors, Coelioxys costaricensis Cockerell, 1914 attacked single and multifemale nests of $E$. atroveneta, but only in one case did the parasite enter a nest and oviposit into a brood cell being provisioned when a Euglossa female was present in the nest; no physical confrontation between parasite and host female was observed. Melittobia is by the first time reported attacking nests of Euglossa. However, the possibility is not excluded that the infestation may have occurred in the laboratory originated from nests of other wasps and bees species also infested by this eulophid and kept near to the nests of $E$. annectans.

In the two re-use processes observed, the associated females were of the same generation and each of them built, provisioned and oviposited in her own cells; these conditions demonstrate a communal association (MICHENER 1974). Although the activities of females sharing the nest 1 during the foundation were not observed, they probably behaved similarly to those females re-using the nests. If this hypothesis is correct, the communal colonies of $E$. annectans may be formed by females moving to already occupied nests and by permanence of two or more females in their natal nests. Although communal nesting have already been showed to occur in Eulaema nigrita (ZUCCHI et al. 1969; PEREIRA-MARTINS \& KERR 1991; SANTOS \& GARÓFALO 1994) and suggested for Euglossa imperialis Cockerell, 1922 and Euglossa ignita Smith, 1874 (ROBERTS \& DODSON 1967), the results obtained in this study provide the first documentation of communality in the genus Euglossa.

ACKNOWLEDGEMENTS. We are grateful to Carlos J.E. Lamas (Museu Nacional, UFRJ), who kindly identified the Anthrax, Edilson S.R. da Silva, for technical help and Claudete Aguiar, Director of the Base de Estudos de Ecologia e Educação Ambiental, and Lauro de Carvalho, for providing excellent facilities for this study.

\section{REFERENCES}

DRESSLER, R.L. 1982. Biology of the orchid bees (Euglossini). Ann. Rev. Ecol. Syst. 13: 373-394. 
EBERHARD, W.G. 1988. Group nesting in two species of Euglossa bees (Hymenoptera: Apidae). Jour. Kansas Entomol. Soc. 61: 406-411.

GARÓFALO, C.A. 1985. Social structure of Euglossa cordata nests (Hymenoptera: Apidae: Euglossini). Entomol. Gener. 11: 77-83.

1992. Comportamento de nidificação e estrutura de ninhos de Euglossa cordata (Hymenoptera, Apidae, Euglossini). Rev. Brasil. Biol. 52: 187-198. 1994. Biologia de nidificação dos Euglossinae (Hymenoptera, Apidae). Anais do $\mathbf{I}^{\mathbf{0}}$ Encontro sobre Abelhas, Ribeirão Preto, 1: 17-26.

Garófalo, C.A.; E. CAMILlo; J.C. SerRano \& J.M.M. RebÊlo. 1993. Utilization of trap nests by Euglossini species (Hymenoptera: Apidae). Rev. Brasil. Biol. 53: $177-187$.

KIMSEY, L.S. 1987. Generic relationships within the Euglossini (Hymenoptera: Apidae). Syst. Ent. 12: 63-72.

LEITÃO-FILHO, H.F. 1992. A flora arbórea da Serra do Japi, p.40-63. In: L.P.C. Morellato (Ed.). História Natural da Serra do Japi: Ecologia e preservação de uma área florestal do Sudeste do Brasil. Campinas, Editora da Unicamp/Fapesp, 321p.

MiCHENER, C.D. 1974. The Social Behavior of the Bees: A Comparative Study. Cambridge, Harvard Univ. Press, 404p.

PEREIRA-MARTINS, S.R. 1991. Biologia de Eulaema nigrita. 2. Atividades nidais. Papéis Avulsos de Zoologia, São Paulo, 37: 237-243.

Pereira-Martins, S.R. \& W.E. Kerr. 1991. Biologia de Eulaema nigrita. 3. Inferências evolutivas. Papéis Avulsos de Zoologia, São Paulo, 37: 245-250.

PINTO, H.S. 1992. Clima da Serra do Japi, p.30-39. In: L.P.C. Morellato (Ed.). História Natural da Serra do Japi: Ecologia e preservação de uma área florestal do Sudeste do Brasil. Campinas, Editora da Unicamp/Fapesp, 321p.

Ramirez-ARriaga, E.; J.I. CuAdRIEllo-Aguilar \& E.M. HeRNÁNDEZ. 1996. Nest structure and parasite of Euglossa atroveneta Dressler (Apidae: Bombinae: Euglossini) at Unión Juárez, Chiapas, México. Jour. Kansas Entomol. Soc. 69: 144-152.

ROBERTS, R.B. \& C.H. Dodson. 1967. Nesting biology of two communal bees, Euglossa imperialis and Euglossa ignita (Hymenoptera: Apidae), including description of larvae. Ann. Entomol. Soc. Amer. 69: 1007-1014.

RouBIK, D.W. 1989. Ecology and Natural History of Tropical Bees. New York, Cambridge Univ. Press, 514p.

SANTOS, M.L. \& C.A. Garófalo. 1994. Nesting biology and nest re-use of Eulaema nigrita (Hymenoptera, Apidae, Euglossini). Ins. soc. 41: 99-110.

YouNG, A.M. 1985. Notes on the nest structure and emergence of Euglossa turbinifex Dressler (Hymenoptera: Apidae: Bombinae: Euglossini) in Costa Rica. Jour. Kansas Entomol. Soc. 58: 538-543.

ZAR, J.H. 1984. Biostatistical analysis. Englewood Cliffs, Prentice-Hall Inc., $2^{\text {nd }}$ ed., $718 \mathrm{p}$.

ZUCCHI, R.; S.F. SAKAGAMI \& J.M.F. CAMARGO. 1969. Biological observations on a neotropical parasocial bee, Eulaema nigrita, with a review on the biology of Euglossinae (Hymenoptera: Apidae). A comparative study. Jour. Fac. Sci. Hokkaido Univ., Zool., 17: 271-380.

Recebido em 25.IV.1997; aceito em 13.VII.1998. 